Король С.Я., д. е. н., доц.

Київський національний торговельно-економічний університет, м. Київ, Україна

\title{
ПЕРСПЕКТИВИ ДИСТАНЦЙНОЇ ОСВІТИ У ЗВО УКРАЇНИ
}

Однією 3 ознак цифрової епохи стала дистанційна освіта 3 використанням сучасних інформаційно-комунікаційних технологій. Вони значно розширили можливості, забезпечили доступність і підвищили якість дистанційного навчання задля здобуття освіти та професійної кваліфікації, а також підвищення їх рівня.

Технології дистанційного навчання нині використовуються у багатьох країнах світу. Україна не залишалась осторонь цих процесів. Законодавчі умови для впровадження в нашій країні дистанційної освіти через Інтернет почали формуватися ще наприкінці 90-х років, коли Законом України «Про національну програму інформатизації» були визначені задачі з інформатизації освіти та освоєння Інтернет.

Нині активне використання технологій дистанційного навчання у середній школі та інформаційно-комунікаційних технологій у всіх сферах життя формує у майбутніх абітурієнтів відповідні очікування щодо навчальних технологій у вищій школі. Перспективи дистанційного навчання становлять інтерес як для слухачів, так і для самих ВНЗ. При цьому для останніх - це можливість розширити коло потенційних абітурієнтів, підвищити рівень підготовки фахівців і власний рейтинг. В Україні ряд названих ВНЗ впровадили дистанційне навчання як окрему форма навчання (за погодженням 3 Міністерством освіти і науки України). Проте, більшість надає перевагу змішаній формі навчання: при денній та вечірній формах навчання. Це обумовлено рядом факторів.

Переваги дистанційної форми навчання для студента обумовлені можливістю заробити диплом з мінімальним порушенням звичного стилю життя та найбільш зручним стилем навчання у кращих навчальних закладах і кращих викладачів. Однак, ступінь довіри до 
такої форми навчання та якість підготовки прямо залежить від доброчесності як слухачів, так і викладачів. Важливе значення також має рівень самоорганізації та відповідальності студента.

Змішана форма навчання $є$ більш прийнятною та ефективною, ніж очна. Вона, зокрема, дозволяе гнучкіше використовувати різні засоби контролю знань студентів, поєднувати дистанційне теоретичне опанування навчального матеріалу 3 виконанням лабораторних завдань у відповідно оснащених аудиторіях навчального закладу.

3 іншого боку, розробка методичного та дидактичного забезпечення всіх видів навчальних занять і контрольних заходів для комплексу дисциплін за навчальною програмою підготовки бакалаврів та магістрів є складним, тривалим, трудомістким і відповідальним процесом. Його реалізація на практиці передбачає освоєння технологій дистанційного навчання за кожною 3 навчальних дисциплін, яка передбачена програмою.

Технологія дистанційного навчання представляє інтерес не лише для осіб з особливими потребами чи хто, наприклад, проживає у віддалених населених пунктах та за кордоном. Вона може зацікавити обдаровану молодь, яка спроможна самостійно прискорено опанувати навчальні програми, бажає паралельно за власним вибором отримувати знання 3 додаткових дисциплін, поєднувати навчання в двох навчальних закладах або навчання з роботою. Зрештою, саме дистанційне навчання $\epsilon$ найбільш зручною і доступною формою підвищення кваліфікації та/або професійної перепідготовки через навчання за короткостроковими дистанційними програмами та отримання другої вищої освіти.

Отже, ВНЗ можуть використовувати технології дистанційного навчання для здійснення довузівської підготовки, підготовки бакалаврів і магістрів, а також професійної перепідготовки та підвищення кваліфікації фахівців.

3 іншого боку, технології дистанційного навчання дозволяють залучати до навчального процесу кращих викладачів та фахівцівпрактиків, з інших населених пунктів чи, навіть, країн для проведення окремих навчальних занять (лекцій, майстер-класів, тренінгів), організації контрольних заходів, науково-дослідної роботи тощо.

Зважаючи на існуючу практику, можемо зробити висновок, що в Україні переваги дистанційного навчання у ВНЗ використовуються не повністю. Процес їх освоєння лише започатковано. При цьому найближчим часом вимоги споживачів освітніх послуг зростатимуть, 
як і можливості інформаційно-комунікаційних технологій, що їх забезпечують. Це дає підстави підтримати тезу Кена Робінсона: в той час, як наша освітня система переживає реформування, насправді вона потребує революції [1].

\section{Список бібліографічних посилань}

1. Ken Robinson. Bring on the learning revolution! [Електронний pecypc]. - Режим доступу : https://www.ted.com/talks/sir_ken_ robinson_bring_on_the_revolution\#t-262875 